\title{
Pokornička slavlja u liturgijskoj praksi
}

\author{
Zvonko PAŽIN* \\ UDK: 27-543.8 • Pregledni članak \\ Primljeno: 19. rujna 2016. P Prihvaćeno: 27. veljače 2017.
}

${ }^{*}$ Izv. prof. dr. sc. Zvonko

Pažin, Katolički bogoslovni fakultet u Đakovu Sveučilišta J. J. Strossmayera u Osijeku, P. Preradovića 17, 31400 Đakovo, Hrvatska, zvonko. pazin@os.t-com.hr

Sažetak: Autor na početku daje kraći povijesni pregled pokorničkoga bogoslužja. U početcima je to bila kanonska pokora za osobito teške grijehe, pokorniku se nametala pokora u zajednici te se jednako tako, nakon ispunjene pokore, takav grješnik pred zajednicom vjernika svečano pomirivao s Bogom i Crkvom. Kada od 8. st. tarifna pokora počinje potiskivati kanonsku, sve se više razvija pojedinačna ispovijed i pomirenje. Nakon Drugoga vatikanskoga sabora ponovno se uvodi mogućnost pokorničkoga bogoslužja u zajednici vjernika. Obrednik na prvo mjesto ipak stavlja red pomirenja pojedinoga pokornika. Drugi je način zajedničko pokorničko slavljes pojedinačnom ispovijedi i odrješenjem. Za izvanredne slučajeve predviđa se i mogućnost općenitoga priznavanja grijeha sa zajedničkim odrješenjem. Konačno, obrednik daje mogućnost i pokorničkoga slavlja, koje bi bilo tek priprava za kasnije sakramentalno pomirbeno slavlje. Autor ističe da je pokorničko slavlje s pojedinačnom ispovijedi $i$ odrješenjem moguće samo onda kada je povoljan omjer ispovjednika i pokornika. Daljnja je mogućnost slavljenja takvoga obreda u manjim skupinama. Kada je riječ o pokorničkim slavljima koja bi trebala biti priprava za pojedinačno pomirenje, autor predlaže oprez da se ne bi dogodilo da vjernici takva nesakramentalna slavlja počnu smatrati sakramentalnima i potpunima.

Ključne riječi: sakrament pomirenja, pokorničko slavlje, nesakramentalna pokornička slavlja, opće odrješenje.

\section{Uvod}

Jedan revni njemački župnik i moj poznanik našao se na godišnjem odmoru u Mađarskoj, negdje na Blatnom jeze- 
ru. Budući da nije znao mađarski, otišao je na nedjeljnu misu kao običan vjernik. Kako ništa nije razumio, priznao je, na misi se obazirao lijevo i desno i zapazio kako se vjernici ispovijedaju. Kakav već jest, Nijemac, gledao je na sat i uočio da su takve ispovijedi trajale 3 - 4 minute. I onda se hvatao za glavu i pitao: »Kakva je to degradacija sakramenta? « No s druge strane taj isti župnik u Njemačkoj brižno je njegovao pokornička slavlja (Bußgottesdienst). Za Božić i Uskrs revno bi pripravljao vodič za takva slavlja s uvodom, čitanjima, psalmima s notama, meditacijama, ispitom savjesti, molitvom za oproštenje grijeha ... Crkva je bila puna, bogoslužje je trajalo otprilike jedan sat. U sklopu toga vjernici su bili upućeni da idućih dana pristupe pojedinačnoj ispovijedi. Rezultat: izuzetno malen broj njih pristupao je pojedinačnoj (sakramentalnoj) ispovijedi. E sada, ako je ono u Mađarskoj (a ista se praksa događa i u nas) degradacija sakramenta pomirenja, kako vrjednovati drugi slučaj, gdje sakramenta zapravo i nema? Kako prosuditi i urediti te dvije dijametralno suprotne prakse? Tražeći odgovor na to pitanje, pogledat ćemo kako su izgledala pokornička slavlja u povijesti te što o tim slavljima govore današnje liturgijske knjige i važeće crkvene odredbe.

\section{Povijesni pregled}

Kao što je poznato, u samim početcima pokora i pomirenje primjenjivali su se samo za osobito teške grijehe. ${ }^{1}$ Već Pavao govori o privremenom isključenju iz zajednice javnoga grješnika da bi ga se kasnije, raskajanoga, moglo opet primiti natrag. ${ }^{2}$ Uskoro se, barem od 2. stoljeća, razvila kanonska pokora koja se nametala samo za posebno teške grijehe. Ona je bila usko povezana sa zajedničkim liturgijskim slavljima. ${ }^{3}$ Valja imati na umu da je biskup bio onaj koji je trebao prosuditi treba li nekome biti nametnuta pokora, odnosno on ju je određivao ovisno o vrsti grijeha. Prema tome, ili je grijeh bio javno poznat ili ga je grješnik ispovjedio biskupu koji je na osnovi toga određivao pokoru i onda pokornika isključio iz zajednice za vrijeme trajanja pokore. Naime, Crkva nije odobravala javno ispovijedanje grijeha. ${ }^{4}$

${ }^{1}$ Za svakodnevne grijehe vjernici su činili redovitu pokoru: post srijedom i petkom, moljenje psalama, vršenje djela kršćanskoga milosrđa, itd.

${ }^{2}$ Usp. 2 Sol 3, 6.14-15; 1 Kor 5, 1-5.9-13; 2 Kor 2, 5-11.

${ }^{3} \mathrm{O}$ kanonskoj i tarifnoj pokori literatura je obimna. Navest ćemo samo nekoliko značajnijih naslova na hrvatskom: D. KNIEWALD, Liturgika, Zagreb, 1937., 285.-288.; A, ADAM, Uvod u katoličku liturgiju, Zadar, 1993., 186.-189.; V. ZAGORAC, Kristova otajstva, Zagreb, 1998., 144.-161.; M. SRAKIĆ, A. JARM (prir.), Pomirbeno slavlje, Đakovo, 1978. Osim toga, nezaobilazne su i ove dvije knjige: C. VOGEL, Il peccatore e la penitenza nella Chiesa antica, Torino-Leumann, 1967.; ISTI, Il peccatore e la penitenza nel medioevo, Torino-Leumann, 1970.

${ }^{4}$ Tako, npr. Leon Veliki veli da se grijesi trebaju ispovjediti prvo Bogu, a onda svećeniku (biskupu). Usp. Ep. 148 u: PL 54 1210-1211, ovdje 2011. Usp. također: C. VOGEL, Il peccatore e la penitenza nella Chiesa antica, 32.-39. 
Evo kako je to zabilježeno u Gelazijevu sakramentaru. ${ }^{5}$ Prvo se donosi obred ulaska među pokornike. ${ }^{6}$ Bio je to liturgijski čin kojim bi grješnik bio službeno odijeljen od ostalih vjernika. Obred se slavio na Pepelnicu: pokornik bi dobio pokornički pojas, bio bi posut pepelom, a nad njim bi onda biskup molio. Nakon ispunjene pokore (koja je trajala od jedne do tri godine) pokornika bi na Veliki četvrtak biskup pred okupljenom zajednicom pomirio (mi bismo rekli, sakramentalno odriješio). ${ }^{7}$ Tom bi prigodom prvo đakon pozvao sve nazočne da mole za pokornika, a biskupa bi molio da pokornika odriješi. Nakon homilije biskup bi nad pokornikom izmolio molitvu pomirenja, čime bi on ponovno postao dionik euharistijskoga zajedništva s ostalima. ${ }^{8}$ Ta je pokora bila neponovljiva, a u isto vrijeme veoma teška jer su i nakon pomirenja ostajale neke pokorničke zabrane, poput one da tako pomireni pokornik ne može sklopiti ženidbu, a ako je već bio u braku, trebao je živjeti u bračnoj suzdržljivosti. Zbog toga su čak i biskupi preporučivali mlađima da kanonsku pokoru odgode do starosti. Uskoro je kanonska pokora izgubila svoje izvorno značenje te

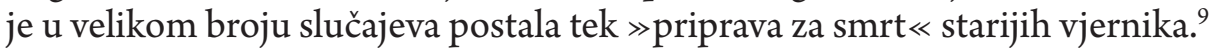

Od 8. stoljeća javlja se tarifna pokora. Novost je u tome da je službenik mogao biti svaki prezbiter, a pokora je bila ponovljiva. Osim kada se, u nekim posebnim slučajevima, nalagala pokora u vidu obveze na hodočašće, iz tarifne je pokore redovito bila isključena zajednica. Bili su dovoljni prezbiter i pokornik. Uskoro je posve nestao zajedničarski vid slavljenja sakramenta pokore. Tako tridentski obrednik ${ }^{10}$ određuje da sakrament pokore slave samo pokornik i svećenik.

\section{Red pokore koji je na snazi}

Prethodne napomene Reda pokore koji je na snazi podijeljene su na šest poglavlja: 1. Otajstvo pomirenja u povijesti spasenja, 2. Pomirenja pokornika u životu Crkve, 3. Službe i dužnosti u pomirenju pokornika, 4. Slavljenje sakramenta pokore,

${ }^{5}$ L. C. MOHLBERG (prir.), Liber sacramentorum Romanae Aeclesiae ordinis anni circuli (Sacramentarium Gelasianum), Roma, 1981. (= GeV).

${ }^{6}$ Usp. GeV 81-83.

${ }^{7}$ Usp. isto $352-363$.

${ }^{8} \mathrm{U} \mathrm{GeV}$ 364-374 donosi i obrasce za pomirenje pokornika u smrtnoj opasnosti.

9 Tako će i danas svećenici reći da često na ispovijed ne dolaze oni koji bi trebali, a oni koji i ne bi trebali dolaze redovito...

${ }^{10}$ Usp. M. SODI, J. J. FLORES ARCAS (prir.), Rituale Romanum. Editio Princeps (1614). Edizione anastatica, Città del Vaticano, 2004., 40.-47. (originalna paginacija) odnosno 48.-55. (paginacija ovog izdanja). Identičan obred nalazimo i u posljednjem izdanju ovoga obrednika: Rimski obrednik izdan po naredbi pape Pavla V. i pregledan brižljivošću drugih papa a oblašću svetog G. N. Pija XI. udešen prema Zborniku kanonskog prava, Zagreb, 1929., 77.-87. 
5. Pokornička slavlja i 6. Prilagodbe obreda pojedinim krajevima i prilikama. ${ }^{11} \mathrm{U}$ spomenutom se četvrtom poglavlju ponovno kao mogućnost predviđa zajedničko slavljenje toga sakramenta. U četvrtom poglavlju Prethodnih napomena ${ }^{12}$ predstavljaju se tri oblika slavlja pokore: A. Red pojedinačnog pomirenja pokornika, ${ }^{13} \mathrm{~B}$. Red pomirenja više pokornika s pojedinačnom ispovijedi i odrješenjem, ${ }^{14} \mathrm{C}$. Red pomirenja više pokornika s općom ispovijedi i odrješenjem..${ }^{15} \mathrm{U}$ petom poglavlju predstavlja se pokorničko (nesakramentalno) slavlje. U obredniku se nude razni tekstovi za slavlje pomirenja, ${ }^{16}$ a u Dodacima (s vlastitom numeracijom) odrješenje od cenzura, ${ }^{17}$ uzorci pokorničkih slavlja ${ }^{18}$ te nacrt ispita savjesti. ${ }^{19}$ Analizirat ćemo sva tri reda i pokorničko (nesakramentalno) slavlje.

\subsection{RED POJEDINAČNOGA POMIRENJA POKORNIKA}

Obnovljena liturgija načelno kao uzor uvijek stavlja ono bogoslužje koje slavi Crkva, zajednica vjernika. Međutim, u ovom slučaju pojedinačno slavljenje kao da ima prednost. Naime, Red pokore taj pojedinačni način stavlja na prvo mjesto te ga tako, na izvjestan način, stavlja kao više redovit. Inače, struktura je skladna i lako provediva. Poslije prijema pokornika ostavlja se prostor za bogoslužje riječi. Nakon ispovijedi grijeha svećenik kaže nekoliko poticajnih riječi, nalaže pokoru i daje odrješenje. Na kraju pokornik i svećenik zajedno daju hvalu Bogu. U praksi se kada ima mnogo pokornika redovito ispušta bogoslužje riječi iz obzira prema onima koji čekaju...

Obrazac odrješenja nov je i vrijedi za svako slavljenje sakramenta pokore. Prvi je dio deprekativan, a zaključni indikativan, ujedno se smatra bitnim za sakramentalno odrješenje:

Bog, Otac milosrda, koji je smrću i uskrsnućem svojega Sina pomirio sa sobom svijet i izlio Duha Svetoga za otpuštenje grijeha, neka ti po službi Crkve udijeli

\footnotetext{
${ }^{11}$ Usp. posljednje hrvatsko izdanje ovog obrednika: Rimski obrednik obnovljen prema odluci svetog općeg sabora Drugog vatikanskog, proglašen vlašću pape Pavla VI. Red pokore, Zagreb, 2009. (= RP). Pojedine dijelove toga obrednika (osim kada su u pitanju Dodaci) navodimo prema brojevima, a ne prema stanicama.

${ }^{12}$ RP, br. 15-37.

${ }^{13}$ Sâm obred se donosi u br. 41-47.

${ }^{14}$ Sâm obred se donosi u br. 48-59.

${ }^{15}$ Sâm obred se donosi u br. 60-66.

${ }^{16} \mathrm{RP}$, br. 67-213.

${ }^{17}$ Isto, 193.

${ }^{18}$ Isto, 195.-250.

${ }^{19}$ Isto, 251.-254.
} 
oproštenje i mir. I ja te odrješujem od grijeha tvojih u ime Oca i sina i Duha Svetoga. Amen. ${ }^{20}$

U vrijeme nastajanja toga obrednika liturgičari su predlagali više formula koje su, prema drevnoj predaji, bile deprekativne. Međutim, prihvaćena je samo gore navedena. ${ }^{21}$

\subsection{RED POMIRENJA VIŠE POKORNIKA S POJEDINAČNOM ISPOVIJEDI I ODRJEŠENJEM}

U prethodnim napomenama stoji: »Kada se zajedno skupi više pokornika za sakramentalno pomirenje, prikladno je da se na nj priprave slavljenjem Božje riječi.« ${ }^{22}$ Dakle, služba riječi u ovome redu pretpostavlja se, što se vidi i iz same strukture navedenoga reda.

Evo osnovne strukture prema Prethodnim napomenama: ${ }^{23}$

- Uvodni obredi

- Slavljenje riječi Božje

- čitanja,

- homilija

- ispit savjesti

- Obred pomirenja

- opća ispovijed grijeha

- pojedinačna ispovijed i odrješenje

- Zahvala za Božje milosrđe i zaključni obred

Za sve te dijelove u Dodacima se nudi više mogućih obrazaca. ${ }^{24}$ Valja primijetiti da zajedničko bogoslužje riječi i ispit savjesti kao priprava za pojedinačnu ispovijed

${ }^{20}$ Isto, br. 46.

${ }^{21}$ Evo dva predložena, a neprihvaćena obrasca. Prvi: Dominus noster Iesus Christus, qui seipsum Patri pro nobis obtulit immolatum, quique Ecclesiae suae potestatem contulit remitendi peccata, ipse te gratia Spiritus Sancti a peccatis tuis per ministerium meum absolvat, atque in perfectam Ecclesiae pacem restituat. Qui vivit et regnat in saecula. Amen. Drugi: Dominus noster Iesus Christus, qui passione et resurrectione sua mundum Patri reconciliavit, Spiritus Sancti gratia per ministerium meum peccata tua remittit, ut in plenam Ecclesiae vitam te restituit. Qui vivit et regnat in saecula. Amen. Vidi: A. BUGNINI, La riforma liturgica (1948-1975), Roma, 1983., 650. (bilješka br. 14).

${ }^{22} \mathrm{RP}$, br. 22.

${ }^{23}$ Isto, br. 23-30.

${ }^{24}$ Usp. RP, Dodatak II. (uzorci pokorničkih slavlja), 195.-250. i III. (nacrt ispita savjesti), 251.-254. Osim toga postoji mnogo modela pokorničkoga bogoslužja. Ističemo: M. SRAKIĆ, A. JARM 
nemaju utemeljenje u tradiciji. Novost je u tome što se središnji dio toga pomirbenoga slavlja, ispovijed i pomirenje, događa privatno i pojedinačno. Ispovijed grijeha, naravno, uvijek treba ostati pojedinačna i tajna. Međutim, u vrijeme priprave toga obreda liturgičari su predlagali da se sakramentalno pomirenje, tj. odrješenje, uz uobičajene uvjete, podijeli svima koji su prethodno u istom slavlju pojedinačno ispovjedili svoje grijehe svećeniku, upravo onako kako je u starini biskup na Veliki četvrtak javno odriješio i pomirio sve one koji su ispunili nametnutu pokoru. Dakle, to ne bi bila novina! $!^{25}$ Međutim, Kongregacija za nauk vjere to nije dopustila i za to nije dala nikakvo objašnjenje. ${ }^{26}$ Iako je liturgijska obnova veoma naglašavala zajednička slavlja svih liturgijskih čina, u ovom slučaju to nije dopušteno. Možda se Kongregacija bojala zloupotreba ili pak krivoga shvaćanja nekih vjernika tako da bi oni na primjer mogli pristupiti takvom skupnom odrješenju bez prethodne pojedinačne ispovijedi. Međutim, to bi se relativno lako moglo riješiti jasnom odredbom da je pojedinačna ispovijed uvjet za valjano odrješenje. ${ }^{27}$

\subsection{RED POMIRENJA VIŠE POKORNIKA S OPĆOM ISPOVIJEDI I ODRJEŠENJEM}

Taj je red predviđen u nekim slučajevima, kad je materijalno nemoguće da se vjernici, bez vlastite krivnje, pojedinačno ispovjede. Uvodne napomene u tome smislu donose jasne odredbe:

31. Pojedinačna i cjelovita ispovijed i odrješenje jedini su redoviti način kojim se vjernik, svjestan teškoga grijeha, pomiruje s Bogom i Crkvom; samo fizička ili moralna nemogućnost ispričava od takve ispovijedi, pa se u tome slučaju pomirenje može postići i na druge načine.

Većem broju pokornika zajedno i bez prethodne pojedinačne ispovijedi opće se odrješenje ne može podijeliti osim:

a) ako prijeti smrtna opasnost te svećeniku ili svećenicima ne dostaje vrijeme da saslušaju ispovijedi pojedinih pokornika;

(prir.), Pomirbeno slavlje, Đakovo, 1978. Osim toga različiti časopisi i brošure donose materijale za takva bogoslužja.

${ }^{25}$ Neki autori donose sljedeći primjer. U slavlju sakramenta potvrde biskup nad svim krizmanicima govori posvetnu molitvu u množini, da bi nakon toga na svakoga pojedinačno položio ruku i pomazao ga. Usp. A. CARIDEO, Analisi teologica e celebrativa del nuovo $\gg$ Ordo Pententiae $\ll$, u: RAZNI AUTORI, La penitenza. Studi biblici, teologici e pastorali. Il nuovo rito della riconciliazione, Leuman (Torino), 1976., 187.-221., ovdje 210.

${ }^{26}$ Usp. A. BUGNINI, La riforma liturgica (1948-1975), 651.

${ }^{27}$ Valja ipak priznati da bi u tome slučaju uvijek ostala mogućnost zloupotrebe. U svakom slučaju, odredba je takva kakva jest. 
b) ako je velika potreba, to jest kada s obzirom na broj pokornika nema dovoljno ispovjednika da saslušaju kako treba ispovijedi pojedinaca unutar prikladnoga vremena, tako da bi pokornici, bez vlastite krivnje bili prisiljeni dugo ostati bez sakramentalne milosti ili svete pričesti; ali se potreba ne smatra dovoljnom ako ispovjednici ne mogu biti na raspolaganju samo zbog dolaska velikog broja pokornika, kao što se može dogoditi na nekoj velikoj svečanosti ili hodočašću.

32. Prosuditi postoje li uvjeti što ih traži br. 31, pripada dijecezanskom biskupu, koji, vodeći računa o kriterijima što su usuglašeni sostalim clanovima konferencije biskupa, može odrediti slučajeve takve nužde.

34. Oni kojima se teški grijesi opraštaju općim odrješenjem neka što prije, kad budu imali priliku, pristupe pojedinačnoj ispovijedi prije nego ponovno prime takvo odrješenje, osim ako su u tome opravdanim razlogom spriječeni. No svakako treba da u roku od godine dana pristupe ispovjedniku, osim ako postoji moralna nemogućnost. I za njih, naime, vrijedi zapovijed koja nareduje svakom kršćaninu da barem jednom na godinu mora osobno ispovjediti svećeniku sve svoje teške grijehe koje nije pojedinačno ispovjedio.

Taj red koji predviđa opću ispovijed i skupno odrješenje nema utemeljenje u tradiciji. Crkvu je naime mnogo više zanimalo obraćenje, pa tek onda samo odrješenje. U tom se slučaju sakrament pomirenja može shvatiti odveć pravnički. Na kraju, taj je red nekako necjelovit jer za pokornika ostaje obveza da sve te (odriješene!) grijehe kasnije ipak ispovijedi u pojedinačnoj ispovijedi. ${ }^{28}$

Određene kontroverze, pa i različitu praksu, unijelo je pitanje kako shvatiti odredbe da se taj oblik pomirenja može uzeti kada postoji »velika potreba «, odnosno u kojim bi se slučajevima moglo reći da bi (bez ovakvoga slavljenja pokore) $\gg$ pokornici, bez vlastite krivnje bili prisiljeni dugo ostati bez sakramentalne milosti $\ll$. U tome je smislu indikativan razvoj takve prakse u Švicarskoj. Švicarski su biskupi 1974. godine izjavili da se takve prilike (velike potrebe kada bi vjernici bez svoje krivice dulje ostali bez toga sakramenta) »u našoj zemlji mogu pojaviti, na primjer, u vremenu priprave za Božić ili Uskrs. Na župnicima je i na rektorima crkava, da prosude ima li takve potrebe. Svjesni svoje odgovornosti, svećenici trebaju djelovati razborito i u skladu sa svojim Ordinarijem $\ll_{.}^{29}$

\footnotetext{
${ }^{28}$ Međutim, u slučaju smrtne opasnosti i taj oblik pomirenja ima veliku važnost i dobro je da postoji takva mogućnost.

${ }^{29}$ ŠVICARSKA BISKUPSKA KONFERENCIJA, Al servizio della riconciliazione, od 7. studenoga 1974., u: RAZNI AUTORI, La penitenza, 384.-391., ovdje 387.-388.
} 
U praksi je pojedinačno ispovijedanje grijeha praktički nestalo jer su vjernici u najvećoj mjeri dolazili samo na takva pokornička slavlja s općim priznavanjem grijeha i zajedničkim odrješenjem. Očito je bilo da se umjetno stvarala takva potreba. Zbog takvih, umjetno stvorenih, nejasnoća Ivan Pavao II. 2002. godine još jedanput pojasnio je značenje odredba iz Reda pomirenja. On naglašava da se taj obred može uzeti u slučaju smrtne opasnosti i u slučaju velike potrebe kada bi vjernici bez svoje krivice ostali dulje vremena bez toga sakramenta, o čemu odlučuje ordinarij usklađen s Biskupskom konferencijom. ${ }^{30}$

U skladu s tim motu proprijem Švicarska biskupska konferencija 1. siječnja 2009. godine revidira svoju raniju odluku i izjavljuje da je osobno i potpuno priznavanje grijeha te pojedinačno odrješenje jedini redovan put kojim se vjernik pomiruje $s$ Bogom i Crkvom. Nadalje, švicarski biskupi u istom dokumentu određuju da se u pokorničkim slavljima odrješenje daje pojedinačno i to nakon osobnoga priznavanja grijeha ili, ako nema pojedinačne ispovijedi, da se to slavlje zaključi običnom deprekativnom molitvom za oproštenje grijeha. ${ }^{31}$ Nadalje se određuje da se skupno odrješenje može podijeliti samo u slučaju neposredne smrtne opasnosti. ${ }^{32}$ Međutim, pokazuje se da je vjernicima izuzetno teško prihvatiti tu odredbu nakon višegodišnje drukčije prakse. Naime, iako u takvim bogoslužjima više nema sakramentalnoga odrješenja, tamošnji vjernici u velikom broju sudjeluju u takvim (nesakramentalnim) pokorničkim bogoslužjima, a nakon toga veoma malen broj njih pristupa pojedinačnoj ispovijedi, kako mogu posvjedočiti svećenici koji tamo djeluju. Ista je situacija i u drugim Crkvama njemačkoga govornoga područja (Austrija, Njemačka), iako tamo nikada nije bilo dopušteno podjeljivati zajedničko odrješenje. Većina vjernika ponaša se kao da (nesakramentalno) pokorničko slavlje zamjenjuje pojedinačnu ispovijed i odrješenje. U nas nije bilo takvih kontroverzi. Biskupska konferencija Jugoslavije na svom je jesenskom saboru 1974. godine odredila:

$\gg$ S obzirom na Norme za podjeljivanje skupnog odrješenja koje je izdala Sveta stolica, Biskupska konferencija smatra da u nas zasada ne postoje uvjeti iz t. 3. spomenutog dokumenta, pa prema tome nema mjesta za po-

\footnotetext{
${ }^{30}$ Usp. IVAN PAVAO II., Apostolsko pismo Motu propij Misericordia Dei, o nekim aspektima slavljenja sakramenta pokore (7. travnja 2002), u: Acta Apostolicae Sedis 94(2002.), 453. Tekst je također dostupan na stranici: http://w2.vatican.va/content/john-paul-ii/it/motu_proprio/documents/ hf_jp-ii_motu-proprio_20020502_misericordia-dei.html (29.VIII. 2016.).

${ }^{31}$ To je redovito formula koja se nalazi u redu mise: »Smilovao nam se svemogući Bog, oprostio nam grijehe naše i priveo nas u život vječni.«

${ }^{32}$ Usp. ŠVICARSKA BISKUPSKA KONFERENCIJA, Revision der Partikularnormen der Schweizer Bischofskonferenz zum neuen Kirchenrecht (Serie VI). Dekret zu can. 961 CIC. Tekst je dostupan na: http://www.bischoefe.ch/dokumente/anordnungen/revision-der-partikularnormen-der-schweizer-bischofskonferenz-zum-neuen-kirchenrecht-serie-vi (29. VIII. 2016.).
} 
djeljivanje takvog odrješenja. Ovaj opći sud BKJ po sebi ne dira prava pojedinog mjesnog ordinarija da za svoje područje odredi drugačije. ${ }^{33}$

Još jedno pitanje. Kada su već predviđena zajednička pokornička slavlja (red pomirenja više pokornika s pojedinačnom ispovijedi i odrješenjem te red pomirenja više pokornika $\mathrm{s}$ općom ispovijedi i pojedinačnim odrješenjem), zašto se to ne bi slavilo pod misom kako su to neki predlagali u vremenu liturgijske reforme, kao što ta mogućnost postoji na primjer u slavljenju krštenja ili vjenčanja? Međutim, to je izričito zabranjeno rješenjem Kongregacije za nauk vjere 1972. godine, ${ }^{34}$ bez nekoga posebnoga obrazloženja. ${ }^{35}$

\subsection{PokorničKa SLAVLJA}

Riječ je o nesakramentalnom slavlju. To je prigodna služba riječi koja vjernike poziva na pokajanje i pripravlja ih za sakramentalno pomirenje koje će (sljedećih dana) uslijediti. Prethodne napomene objašnjavaju korist i značenje tih slavlja:

Treba paziti da se ta slavlja u vjerničkom mnijenju ne pobrkaju sa samim slavljenjem sakramenta pokore. Ta su pak pokornička slavlja veoma korisna za promicanje obraćenja i očišćenja srca.

Pokornička slavlja zgodno se upriličuju osobito s ovim ciljevima:

- da se njima u kršćanskoj zajednici promiče duh pokore;

- da se vjernicima pomogne u pripravi na ispovijed koju pojedinci kasnije, u pogodno vrijeme, mogu obaviti;

- da odgajaju djecu kako bi postupno oblikovala svoju savjest o grijehu u ljudskom životu i o oslobođenju od grijeha po Kristu;

- da se pomogne katekumenima u obraćenju.

${ }^{33}$ BISKUPSKA KONFERENCIJA JUGOSLAVIJE, Uputa o pomirenju za svećenike, Zagreb, 1976., 18.-19. Međutim, u Domovinskom ratu zbog očite neposredne smrtne opasnosti svećenici su s vojnicima slavili treći oblik, to jest Red pomirenja više pokornika s općom ispovijedi i odrješenjem. Međutim, ponekad su neki svećenici zlorabili tu odredbu jer su podjeljivali opće odrješenje i u vrijeme primirja, kada bi vojnici išli na položaj odraditi svoju smjenu, nakon čega bi išli svojim kućama. Dakle, oni su se mogli redovito ispovijedati prije svoje smjene.

${ }^{34}$ Usp. KONGREGACIJA ZA NAUK VJERE, Sacramentum poenitentie. Normae pastorales circa absolutionem sacramentalem, 16. iunii 1972, br. X., u: R. KACZYNSKI (prir.), Enchiridion documentorum institutionis liturgicae, I (1963-1973), Marietti, 1976., br. 2828, 873. Međutim, poznato mi je da se u nekim crkvama upravo tako čini: vjernici se skupe u crkvi, župnik započne misu te nakon prigodne homilije pozove druge svećenike da pojedinačno ispovijedaju vjernike i nakon toga nastave misu s pripravom darova ... Možda to jest u duhu liturgije, ali je izravno protiv crkvenih odredaba.

${ }^{35}$ Paradoksalno je da se s druge strane tolerira pojedinačno ispovijedanje za vrijeme mise! 
Osim toga, gdje nema svećenika koji bi podijelio sakramentalno odrješenje, pokornička su slavlja silno korisna jer pomažu da se vjernici raspolože za čin savršenog pokajanja iz ljubavi, kojim, u želji buduće sakramentalne pokore, mogu postići Božju milost. ${ }^{36}$

Ustrojstvo je pokorničkoga slavlja kao i u drugim slavljima Božje riječi:

- uvodni obredi (pjesma, pozdrav, molitva)

- citanje Svetoga pisma, pjevanje psalama, homilija, ispit savjesti

- molitva okupljenih vjernika (pokajanje)

- molitva Gospodnja pri čemu se naglašava »otpusti nam duge naše kako i mi otpuštamo dužnicima našim ... « i »izbavi nas od zla «

- zaključna molitva (eventualno zazivanjem Božjega oproštenja) i otpust naroda.

Takva bogoslužja može predvoditi i laik. Iako bi ta slavlja trebala biti tek priprava za pojedinačno priznavanje grijeha i pojedinačno odrješenje koje daje svećenik, u crkvama njemačkoga govornoga područja najveći dio onih koji sudjeluju u pokorničkim nesakramentalnim slavljima, kao što smo spomenuli, nakon toga ne pristupaju pojedinačnoj ispovijedi. ${ }^{37}$

\section{Mogućnosti i perspektive}

Svako je bogoslužje u Crkvi nužno zajedničarsko, odnosno slavlje cijele Crkve snagom Duha Svetoga (kao što primjerice čak i privatno moljenje časoslova predstavlja čin Crkve). Zato ćemo ukratko predstaviti mogućnosti koje u tome smislu pruža red pomirenja pojedinih pokornika, a veću ćemo pozornost, naravno, posvetiti mogućnostima koje pruža red pomirenja više pokornika s pojedinačnom ispovijedi i odrješenjem te mogućnostima koje pružaju Pokornička (nesakramentalna) slavlja. Budući da je naša Biskupska konferencija izjavila da u nas nema potrebe slaviti pomirenje više pokornika s općom ispovijedi i odrješenjem, mogućnosti toga reda ne ćemo posebno obrađivati.

\footnotetext{
${ }^{36}$ RP, br. 37.

${ }^{37}$ Da se takvo slavlje ne bi pobrkalo sa sakramentom pomirenja, neki materijali iz njemačkoga govornoga područja za pokornička slavlja ne predviđaju čak ni deprekativnu molitvu za oproštenje grijeha ( $\gg$ Smilovao nam se svemogući Bog... «) da bi tako vjernike ipak više potaknuli upravo na sakrament pomirenja. Usp. na primjer Pokorničko slavlje za Godinu milosrđa koje je priredila Liturgijska komisija biskupije Eichstätt. Vidi: http://www.bistum-eichstaett.de/fileadmin/glaubeund-leben/heiliges-jahr/Bussgottesdienst_Fastenzeit.pdf (29. VIII. 2016.).
} 


\subsection{RED POMIRENJA POJEDINIH POKORNIKA}

Valja imati na umu da je i red pojedinačnoga pomirenja pokornika zajedničarski čin jer se svako bogoslužje, pogotovo ono sakramentalno, odvija u Crkvi i s Crkvom snagom Duha Svetoga. Zato bi bilo važno nastojati njegovati službu riječi (ili barem kraće svetopisamsko čitanje) jer je i iz toga vidljivo da nije riječ tek o susretu ispovjednika i pokornika. Čitanje Božje riječi ukazuje nam na djelovanje Duha Svetoga koje se događa u Crkvi. To se pogotovo može i treba ostvariti u ispovjednim razgovorima, tj. uz ispovijedi povezane s duhovnim vodstvom u kojima pokornik $\mathrm{i}$ ispovjednik imaju na raspolaganju dovoljno vremena. Jednako tako, kada god je to moguće, iz istoga razloga bilo bi važno da to slavlje bude u sakralnom prostoru.

\subsection{RED POMIRENJA VIŠE POKORNIKA S POJEDINAČNOM ISPOVIJEDI I ODRJEŠENJEM}

Budući da postoji mnogo obrazaca i materijala za to slavlje (a i sam ih obrednik nudi), ne bi trebalo biti osobito teško pripraviti to bogoslužje. Naravno, svaki ponuđeni materijal potrebno je prilagoditi određenoj zajednici. Kao u svakom bogoslužju, važno je da se obredu dadne duša, a ne da se samo iščita ono što piše. Evo napomena uz određene mogućnosti.

\subsubsection{Povoljan omjer ispovjednika i pokornika}

To slavlje, rekli bismo, ne bi trebalo trajati dulje od nedjeljne mise, dakle do jednoga sata. Zbog toga je presudno da bude povoljan omjer broja pokornika i ispovjednika. Naravno, važna je i određena disciplina pokornika jer je potrebno doći u točno određeno vrijeme, što može biti problem tamo gdje su vjernici naviknuli da velika ispovijed traje tijekom cijeloga dana. Na župniku je, odnosno na rektoru crkve, da procijeni je li moguće, s obzirom na broj raspoloživih ispovjednika, za cijelu zajednicu ponuditi taj red pomirenja.

\subsubsection{Pojedine skupine}

U većini župa teško će se za cijelu zajednicu moći ostvariti takvo pokorničko slavlje jer se redovito ne može naći dovoljan broj ispovjednika. Međutim, red pomirenja više pokornika s pojedinačnom ispovijedi i odrješenjem može se razmjerno lako upriličiti s određenom (manjom) skupinom vjernika. To mogu biti određene katehetske skupine (djeca, krizmanici, mladi), kao i pojedine skupine i duhovni pokreti u župi, odnosno određena katolička društva. Izvrsna prigoda mogu biti i duhovne vježbe ili obnove, zatim hodočašća. Naravno, pri tome valja poštovati savjest svakog sudionika da se ne bi osjećali prinuđenim pristupiti sakramentalnoj ispovijedi. Jednako tako, u skladu s načelima katoličke moralke, valja omogućiti vjernicima 
slobodu izbora ispovjednika. U svakom slučaju, po sebi je razumljivo da određeni duhovni susreti budu prigoda i za sakramentalno pomirenje. $S$ druge strane, takvo slavlje može uvelike pomoći vjernicima iz takvih skupina da dublje i osobnije shvate prirodu grijeha i veličinu Božjega praštanja koje se događa snagom Duha Svetoga po službi Crkve.

\subsubsection{Mogućnosti u svetištima}

Posebno je pitanje mogućnost takvih slavlja u svetištima. Na pojedine velike svetkovine (npr. svetkovina Velike Gospe u velikim marijinskim svetištima) uz najbolju će volju biti teško postići onaj povoljan omjer pokornika i ispovjednika. Međutim, ovdje bi trebalo računati na dulje staze. Naime, bilo bi dobro ustaliti određenu praksu i tradiciju prema kojoj bi se određenoga dana upriličilo upravo takvo bogoslužje (kao što na primjer u takvim svetištima redovito postoji tradicija da u određeno vrijeme bude pobožnost križnoga puta). I u tome slučaju bit će, naravno, onih koji će se i dalje ispovijedati kao i do sada, međutim dobro je znati da npr. uoči neke svetkovine u određeno vrijeme bude upravo takvo slavlje nakon kojega može slijediti misa.

\subsubsection{Služba riječi na početku velikih ispovijedi}

Budući da sâm obrednik bogoslužje riječi u tome obredu, kao što je već bilo rečeno, naziva pripravom, tj. dijelom pokorničkoga slavlja, ${ }^{38}$ moguće je da takva priprava bude i na početku velike ispovijedi. $\mathrm{U}$ tome slučaju obred je praktično isti kao $\mathrm{i}$ u prethodnim primjerima. Međutim, budući da takve ispovijedi traju više od dva sata, na njemu će sudjelovati samo oni koji prvi dođu. ${ }^{39}$ Osim toga, u tome slučaju nema mjesta za zajedničku zahvalu. Međutim, vrijedi vjernicima ponuditi i taj skraćeni oblik.

\subsection{PoKorničKa SLAVLJA}

Rekao bih da je u našim prilikama teže ostvarivo da cijela župna zajednica dođe na pokorničko (nesakramentalno) slavlje da bi se onda prvom prigodom (sljedećih nekoliko dana) pojedinačno ispovjedili. Naime, kada dođu da pokorničko slavlje, vjernici se žele i pojedinačno ispovjediti (da ne dolaze dva puta). Osim toga, rekao bih, valja biti oprezan s eventualnim uvođenjem takve prakse. Vidjeli smo kako je prenaglašavanje i krivo shvaćanje pokorničkih slavlja u Crkvama njemačkoga govornoga područja dovelo do velikoga opadanja sakramentalne ispovijedi. Međutim, takvo bi se slavlje u nas moglo upriličiti s određenim skupinama. Npr. u sklopu

\footnotetext{
${ }^{38}$ Usp. RP, br. 22.

${ }^{39}$ Poznato je da zbog velikoga broja pokornika vjernici ne dolaze u isto vrijeme.
} 
župne kateheze kateheta (ne nužno svećenik) održi pokorničko slavlje sa svojom skupinom u tjednu kada je u župi predviđena velika ispovijed ili, jednostavno, za svaku se katehetsku skupinu uzme takvo slavlje na početku došašća i korizme. To onda može vrijediti i za sve gore spomenute skupine (udruge, pokreti). Međutim, rekao bih, bilo bi puno razboritije, koliko god je to moguće, da pokornička slavlja i po skupinama budu sakramentalna. Tako bi se izbjegla opasnost da se sakramentalno slavlje u svijesti nekih vjernika zamijeni nesakramentalnim.

\section{Zaključak}

Posve je jasno da je liturgija zajedničarsko slavlje Crkve. Međutim, bilo bi posve krivo pojednostavljivanje kada bismo tvrdili da crkvenost nekoga slavlja bitno ovisi o broju sudionika. Onda bi naime bilo kvalitetnije misno veleslavlje s tisućama vjernika od nedjeljne mise u maloj filijali s pedesetak vjernika. Dosljedno tome, kada je u pitanju slavljenje sakramenta pomirenja, u modernim liturgijskim tokovima preferira se red pomirenja više pokornika s pojedinačnom ispovijedi i odrješenjem naspram reda pojedinačnoga slavljenja. Rekao bih da se i u liturgiji valja čuvati pomodnosti. Kao što je u svijetu mode nešto in, a nešto out i o tome se ne raspravlja, tako se ponekad neki dijelovi liturgije predstavljaju kao in, dok su drugi out i to u prilično crno-bijelom shvaćanju stvari.

Kao prvo, nema nikakvoga razloga da se red pojedinačnoga slavljenja pomirenja smatra manje poželjnim i manje vrijednim. Konačno, svako liturgijsko slavlje jest nužno slavlje Crkve snagom Duha Svetoga. Prisjetimo se. U obredniku je taj red na prvom mjestu. Nadalje, vidjeli smo kako prenaglašavanje zajedničkoga slavljenja sakramenta pokore može dovesti do krivoga shvaćanja prirode toga sakramenta sve do njegova iščeznuća u praksi mnogih zapadnoeuropskih vjernika. A to nije bila namjera. Upravo zbog toga noviji mjesni (Švicarska) i opći akti naglašavaju da je pojedinačna ispovijed i pomirenje bitno.

Nadalje, čini mi se da se posebna mogućnost pruža upravo u slavljenju toga sakramenta s pojedinim manjim skupinama. Nesakramentalna pokornička slavlja kao priprava za pojedinačnu ispovijed zacijelo će biti korisna u katehetskim skupinama.

Vratimo se pitanju postavljenom na početku. Što je bolje? Praksa koju je onaj svećenik vidio u Mađarskoj ili ona koju je on imao u vlastitoj župi u Njemačkoj? Stara mudrost veli: » In medio virtus « (»Vrlina je u sredini.«), to jest izbjegavati krajnosti. Kao i uvijek, valja slijediti pozitivne liturgijske odredbe i preporuke, pogotovo prethodne napomene svake liturgijske knjige. $U$ tome će slučaju svaki od načina koji predviđa obrednik naći svoje mjesto ovisno o prilikama i pastoralnoj razboritosti onih kojima je povjerena briga za bogoslužje u župnoj zajednici. 


\title{
PENITENTIAL CELEBRATIONS IN LITURGICAL PRACTICE
}

\author{
Zvonko PAŽIN*
}

Summary: The author first gives a short historical overview of the penitential celebration. In the beginning, it was a canonical penance for particularly grave sins where the penitent was imposed a penance in the community, and equally so - after the penance - the sinner would solemnly reconcile himself to God and the Church before the community of believers. From the 8th century, when the tariff penance started to replace the canonical penance, there is an increasing development of individual confession and reconciliation. After the Second Vatican Council, the possibility of a penitential service in the community of believers is re-introduced. However, the book of rites prioritizes the order of reconciliation of an individual penitent. Another way is the common penitential celebration with individual confession and absolution. For exceptional cases there is the possibility of a general recognition of sin with the common absolution. Finally, the book of rites allows the possibility of penitential celebration, which would be only a preparation for a later sacramental celebration of reconciliation. The author points out that the penitential celebration with individual confession and absolution is possible only when there is a favorable ratio of confessors and penitents. A further possibility of celebrating this kind of ceremony is in small groups. As for the penitential celebrations that should be a preparation for individual reconciliation, the author suggests caution, that the believers do not start to regard such non-sacramental celebrations as sacramental and complete.

Keywords: Sacrament of Reconciliation, penitential celebration, non-sacramental penitential celebrations, general absolution.

\footnotetext{
* Assoc. Prof. Zvonko Pažin, Ph. D., Catholic Faculty of Theology in Đakovo, J. J. Strossmayer University of Osijek, P. Preradovića 17, 31400 Đakovo, Croatia, zvonko.pazin@os.t-com.hr
} 